\title{
Spatial Perspective on Thermal Comfort and Energy Consumption: a PLS-SEM approach
}

\author{
Bayu Andalas ${ }^{1,2}$, Haryoto Kusnoputranto ${ }^{2}$, Suyud Warno Utomo ${ }^{2,3}$ and Raldi H. Koestoer ${ }^{2,4}$ \\ Jakarta Provincial Government, Jl. Medan Merdeka Selatan Kav.8-9 Jakarta Pusat, Jakarta, 10000, \\ Indonesia $^{1}$ \\ School of Environmental Science, University of Indonesia, Jl. Salemba Raya, Jakarta Pusat, Jakarta, \\ 10000, Indonesia $^{2}$ \\ Faculty of Public Health, University of Indonesia, Depok, Indonesia ${ }^{3}$ \\ Coordinating Ministry for Economic Affairs, Republic of Indonesia, Jakarta, Indonesia ${ }^{4}$
}

Corresponding author: bayu.andalas@ui.ac.id

\begin{abstract}
Jakarta has implemented Environmentally-friendly buildings and Energy-saving act policy. But the energy consumption in a building is moderately increased all the time. It dominated by consumption in building's air conditioner and related to thermal comfort for building's occupants and also the work performance of civil services employees. This research is providing statistical questionnaire-based of subjective answers by a public service employee of Jakarta Capital Government. This study was conducted by concerning spatial perspective or geographic location of the object in six administrative parts of Jakarta Capital City (center, east, north, west, south and Seribu archipelago). The questions is spreads to 367 buildings occupants during the dry-wet season (October-November). The study were performed in 311 Public service facility, then the data is analyzed by Partial Least Square Structural Equation Modeling (PLS-SEM) method to answer research questions about the link between thermal comfort and energy consumption. The results showed a significant result between two variables. A model using those variables was generated to show the link between them and suggested as a tool to conduct better building-related policies in Jakarta Provincial Government.
\end{abstract}

Keywords: Sustainable Building, Thermal Comfort, Energy Saving, Structural Equation Modelling

\section{Introduction}

Green building policy exists in Jakarta Capital City Government since 2012, but ironically, the energy consumption in a building is still increased all the time (Pemprov DKI, 2015). In several types of research [1], buildings consuming energy more than $40 \%$ in general global energy, and also provide more than $30 \% \mathrm{CO} 2$ in general. This is mainly caused by the usage of Air Conditioning System which impacted by building occupants' thermal comfort, especially in the tropical region city like Jakarta [2].

Jakarta Provincial Government in this regime is eager to increase civil service employee's productivity (Pemprov DKI, 2017). To provide better services to its inhabitants, Jakarta Provincial Government built standardized 311 regional offices in its sub-district (267) and 
district (44) to provide any administrative services. The building Indoor Air Quality become a critical part of making the building occupant's comfort [3]. Every district offices and sub-district offices equipped with AC (Air Conditioner) in its service area or the working office, which will consume more energy to provide better services.

The current condition is not compatible with Sustainable Development principles by Salim and UN's Sustainable Development Goals (Salim, 2015). Research conducted by [4] shows a link between Thermal comfort and energy consumptions. Thus variables also appear in research by [5] which show a connection between thermal comfort and work performance also a connection between energy consumptions and environmental-friendly perception of building's occupants.

\section{Literature Review}

This research expected to examine the link between variables and visioned to develop a policy for environmentally friendly (low energy) state-owned government office to the environmentally-friendly concept and better work performance in buildings occupant.

\subsection{Thermal Comfort}

According to [6], Thermal comfort is influenced by physical condition of the buildings and also influenced by the individual preference [7]. in this study the seven-point scale of ASHRAE used in the questionnaire based on method developed by [8].

\subsection{Work Performance}

Work performance of the building's occupants is related to thermal comfort [9] and [10], a modified work performance parameters from [9] deployed in this research is focused on work performance of civil servant employee of Jakarta Capital City Government based on questionnaire survey.

\subsection{Environmentally-friendly perception}

Environmentally-friendly perception in every building is measured by asking questions to each building occupants or building user, the question is adapted from [11] and [12], the question designed to determine how the building occupants aware and percept to environmentally friendly concept.

\subsection{Spatial Perspective}

Several researcher had discovered a link between geographical location to thermal comfort such as research by [13] or research by [14] in Jaipur India and [15] in Vietnam, mention how urban heat and temperature will be different based on locations and elevation of the measured object. In figure 1. below shown the location of each objects of each public building facility in Jakarta, Indonesia. 


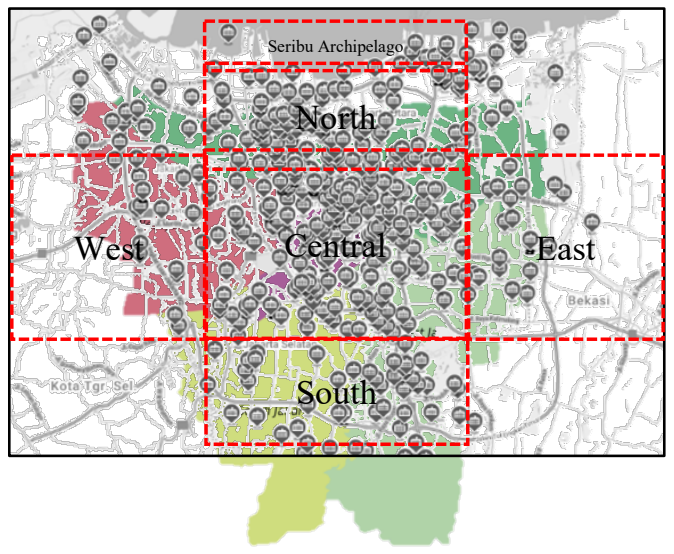

Fig. 1. State-Owned Buildings locations in Jakarta Capital City

\subsection{Building Energy Consumption}

This research has is focused how human interacted with its building and impacted to building energy consumption, so the research focused in its human interaction based on research by [16] and also research by [17] a set of questions is arranged to measure people's perception to building energy consumption.

\section{Hypotheses}

The hypotheses of this research is to examine:

Ha1: Thermal comfort influencing Building Energy Consumption

Ha2: Building perception to sustainable has a correlation to energy consumption

Ha3: Thermal comfort in government building influencing building occupants work performance

Ha4: Thermal comfort has a correlation to work satisfaction

Ha5: $\quad$ Public facility building will be environmentally sustainable if consider thermal comfort and work satisfaction

\section{Materials and methods}

This study is consist of: Subjective questionnaire survey to examine thermal comfort, work performance and environmentally friendly perception of 367 building occupants by adapting the questionnaire method of [8]. The variables compared to the energy consumption of 311 administrative office buildings by determine the Building Energy Consumption.

Population in this research is divided into 2(two) kinds as follows following method developed by [18]: (a) Building Occupants is a civil service employee who work in a state-owned (Jakarta Provincial Government) building counted 67.809 peoples consist of 33.477 (49.36\%) males and $34.332(50,63 \%)$ females and (b) State-owned buildings counted 311 buildings located in several locations (North, Central, South, East, West and Seribu Archipelago) of Jakarta Capital City Territory. Based on Slovin's equation in [19] a minimum 367 samples of civil service 
employee and based on Tabachnick's equation [20], 58 buildings should be examined to conduct the research with a typical condition and shape like in the figure below:
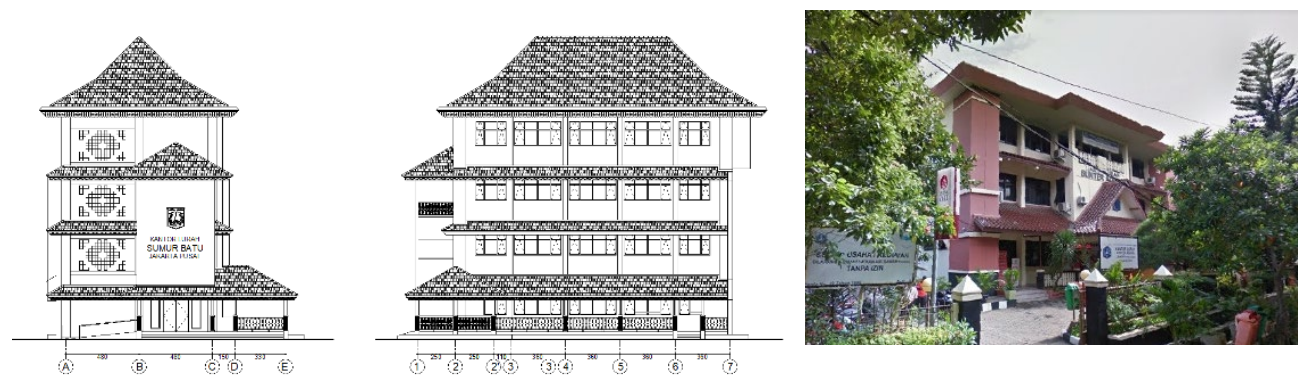

Fig. 2. Typical Government Office in Jakarta

To compare the answers by the individual building occupants with the physical conditions of the buildings, this research using direct measurement of the physical condition of the building while the e-questionnaire spread during the office hour in each building.

Link between Environmental friendly perception and work satisfaction is appeared in several research like [21] and [22], then a connection between Environmentally friendly perception and energy consumption appear in many researh such as [5], [12], [23] every research mentioned above show a direct relation and mutual relationship between both variables, the rest variables such as Thermal Comfort, Energy performance and work satisfaction is appeared in several research such as: [4], [9], [10], [17], [24]. Based on literature review studies to understand link and connection between variables, a chart is established in figure below:

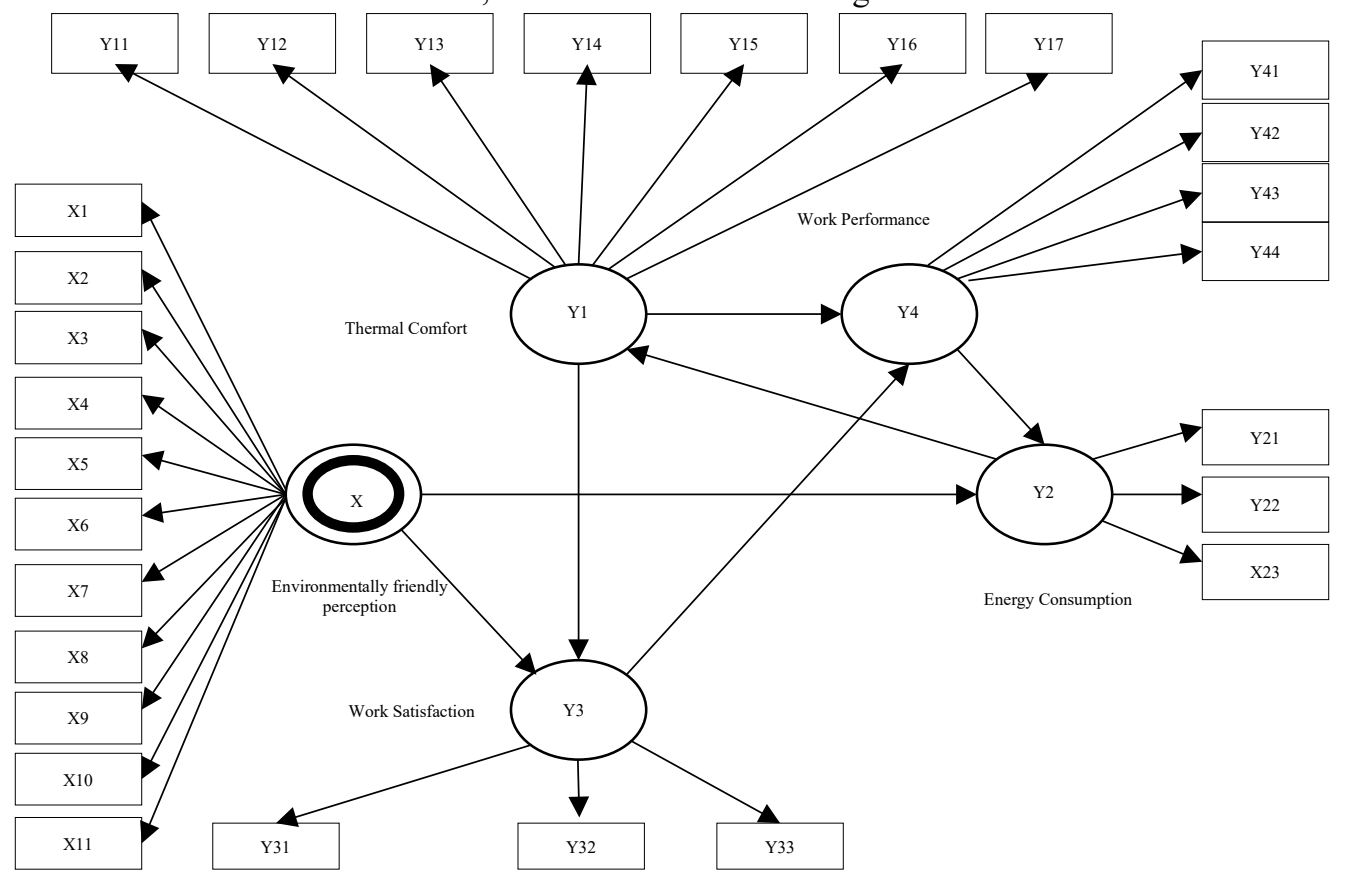

Fig. 3. PLS-SEM model 
to examine quantitavely between variables so Partial Least Structural Equation Modelling (SEM) were used to understands link using subjective questionnaire as shown in Figure 2. Those variables are measured in PLS-SEM using these assessments criteria based on research question in each criteria based on research by [25] in Table.1:

Table 1. Variables and Questions

\begin{tabular}{|c|c|}
\hline No & Objectives \\
\hline \multicolumn{2}{|c|}{ Independent Variables } \\
\hline $\mathbf{X}$ & Environmentally-Friendly Perception \\
\hline $\mathrm{X}_{1}$ & Environmentally-friendly material \\
\hline $\mathrm{X}_{2}$ & Water Conservation \\
\hline $\mathrm{X}_{3}$ & Water Conservation and Rain Harvesting \\
\hline $\mathrm{X}_{4}$ & Energy Diversity \\
\hline $\mathrm{X}_{5}$ & Ozone Friendly Material \\
\hline $\mathrm{X}_{6}$ & Energy Efficient Lighting and Air Conditioning \\
\hline $\mathrm{X}_{7}$ & Domestic Waste Water Management \\
\hline $\mathrm{X}_{8}$ & Waste Separation \\
\hline $\mathrm{X}_{9}$ & Indoor Health Quality \\
\hline $\mathrm{X}_{10}$ & Sustainable Site \\
\hline $\mathrm{X}_{11}$ & Disaster Risk Facilities \\
\hline \multicolumn{2}{|c|}{ Dependent Variables } \\
\hline $\mathbf{Y}_{1}$ & Thermal Comfort in Public Facility/Government Building \\
\hline $\mathrm{Y}_{1} 1$ & Indoor Activity \\
\hline $\mathrm{Y}_{12}$ & Daily Activities \\
\hline$Y_{13}$ & Clothing \\
\hline $\mathrm{Y}_{14}$ & Thermal Comfort Perception \\
\hline $\mathrm{Y}_{15}$ & Thermal Comfort Desire \\
\hline$Y_{16}$ & Thermal Comfort Satisfaction \\
\hline$Y_{17}$ & Thermal Comfort Dissatisfaction \\
\hline \multicolumn{2}{|c|}{ Dependent Variables } \\
\hline $\mathbf{Y} 2$ & Identifying Energy Consumption Perception \\
\hline Y21 & Knowledge of Energy Consumption \\
\hline Y22 & Understanding of Decreasing/Increasing Energy Consumption \\
\hline Y23 & Understanding of using air conditioning device in room \\
\hline \multicolumn{2}{|c|}{ Dependent Variables } \\
\hline $\mathbf{Y}_{3}$ & Work Satisfaction \\
\hline $\mathrm{Y}_{3} 1$ & My Work \\
\hline $\mathrm{Y}_{3} 2$ & Work Evironment Satisfcation \\
\hline $\mathrm{Y}_{3} 3$ & Air Environment Satisfaction \\
\hline \multicolumn{2}{|c|}{ Dependent Variables } \\
\hline Y4 & Work Performance \\
\hline $\mathrm{Y}_{4} 1$ & Presence/Work Disc \\
\hline $\mathrm{Y}_{42}$ & Work Quantity \\
\hline $\mathrm{Y}_{43}$ & Budget Spending \\
\hline $\mathrm{Y}_{44}$ & Behaviour \\
\hline
\end{tabular}




\section{$5 \quad$ Analytical methods}

In this research, the data is analyzed using SPSS Statistics v.24 and SmartPLS v.3.2.2 [26], the PLS is used due to the limitation of the data gathered from the respondents. Variance based PLS-SEM also used because PLS-SEM able to handle reflective and formative model which included in the proposed model of this research [27]. Moreover, PLS-SEM preference are made because of its ability to estimate causal relationship in every latent construct in single time/realtime while a pact with errors of measurement in a structural model.

[28] also suggest measurement model should be evaluated in different way while evaluating the structural model. Moreover, in order to make sure the data consistency and quality of structural model, several other test should be performed while conducting other validity and reliability checks before conducting analysis of PLS-SEM.

Based on guideline performed by [26] an evaluation to assessment criteria should be made to consider each questions be made correctly, the assessment criteria are shown in Table 2.

Table 2. Assessments criteria

\begin{tabular}{|c|c|c|}
\hline Evaluation & Indicators & Assesment \\
\hline \multirow[t]{4}{*}{ Outer Model } & 1.Indicator reliability & $\begin{array}{l}\text { Outer loading value } 0,5 \text { to } 0,7 \text { due to } \\
\text { exploratory research }\end{array}$ \\
\hline & 2.Discrimninant validity & $\begin{array}{l}\text { Variable indicator to latent variable } \\
\text { Cross loading value should be higher } \\
\text { rather than another latent variable } \\
\text { Fornell-Lacker of every latent } \\
\text { variable should be higher than latent } \\
\text { variables correlation }\end{array}$ \\
\hline & 3. Internal consistency & $\begin{array}{l}\text { Composite reliability } \geq 0,6 \\
\text { Cronbach's alpha } \geq 0,6 \\
\text { Composite reliability } \geq 0,8\end{array}$ \\
\hline & 4.Convergent validity & $\begin{array}{l}\text { Average Variance Extracted (AVE) } \\
\text { should be higher than } 0,5\end{array}$ \\
\hline Inner Model & $\begin{array}{l}\text { Determinant Coefficient }\left(\mathrm{R}^{2}\right) \\
\text { Structural Model Coefficient }\end{array}$ & $\begin{array}{l}\mathrm{R} 2>0,75 \text { value is good } \\
\text { Significant }\end{array}$ \\
\hline
\end{tabular}

\section{Respondent Demographic}

By examining the Location, educational level, and the age of the respondents specific understanding of thermal comfort and its supporting factors based on each geographical locations could be examined. Complete details about the respondents' demographic attributes are listed in Table 3.

Table 3. Demographic of Respondents

\begin{tabular}{llllll}
\hline Age years old (yo) & Sum & $\%$ & Location & Sum & Percentage \\
\hline
\end{tabular}




\begin{tabular}{cccccc}
\hline Under 18 yo & 0 & $0 \%$ & Central & 61 & $17 \%$ \\
$18-24$ yo & 5 & $1 \%$ & North & 62 & $17 \%$ \\
$25-34$ yo & 83 & $23 \%$ & East & 86 & $23 \%$ \\
$35-44$ yo & 115 & $31 \%$ & South & 103 & $28 \%$ \\
$45-44$ yo & 134 & $37 \%$ & West & 53 & $14 \%$ \\
$55-64$ yo & 30 & $8 \%$ & Thousand & 2 & $1 \%$ \\
\hline & 367 & $100 \%$ & & 367 & \\
\hline
\end{tabular}

During the survey, most respondents has an undergraduate degree education (Undergraduate/equal 54\% and graduate degree 31\%), so the questionnaire question confirmed to be understandable by the respondents. In the survey, respondents given a set of questions using a digital questionnaires in a cellphone applications with each questions asked individually. The questionnaire spreads during office hour GMT 07:30-17:00 and under specific month (September-October), these month is an intermediary month between dry-wet season in tropical area region like Jakarta $(\mathrm{BMKG}, 2018)$ recorded during these month the outdoor humidity level will be higher than other months. Hopefully, The objective to understand the thermal comfort will be achieved.

By using bootstrapping in PLS-SEM, each questions is measured and resulting value as follow:

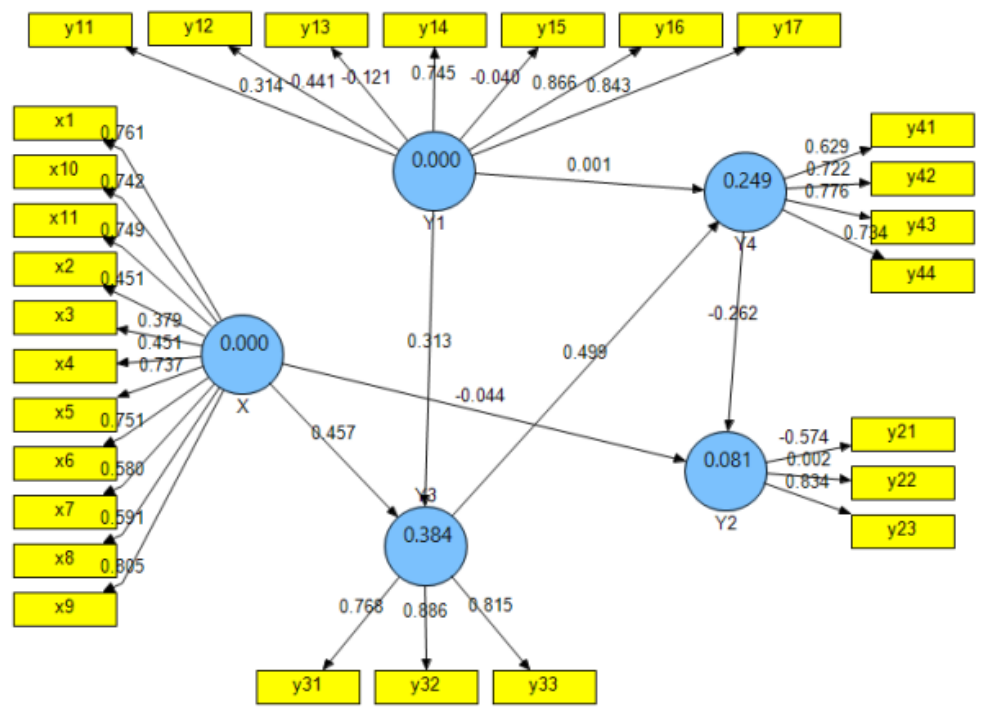

Fig. 4. Bootstrapping in PLS-SEM

\section{$7 \quad$ Results and Discussions}

Each variables (independent and dependent) divided into several objectives and questions as follow, every questions in the variables is merged to the PLS-SEM model as appeared in Fig.1, with several question reflecting every objective in the questionnaires. The result show Thermal 
Comfort and Energy Consumption variables did not meet the criteria of Internal Consistency with the value of Composite reliability $\geq 0,8$, the result shown in Table 4 .

Table 4. Variables and result

\begin{tabular}{cccc}
\hline Latent Variables & $\begin{array}{c}\text { Composite } \\
\text { Reliability }\end{array}$ & Cronbachs Alpha & Results \\
\hline Environmentally-friendly perception & 0.886 & 0.869 & Meet Criteria \\
$(\mathrm{EF})$ & & & Not Meet \\
Thermal Comfort (TC) & 0.501 & 0.280 & Criteria \\
Energy Consumption (EC) & 0.034 & 0.456 & Not Meet \\
Work Satisfaction (WS) & 0.864 & 0.765 & Criteria \\
Work Performance (WP) & 0.808 & 0.692 & Meet Criteria \\
\hline
\end{tabular}

Furthermore, each question in every variable also measured to understand the validity of each questions to fit the proposed model, the results are shown below in Table 5:

Table 5. Variables and conclusion

\begin{tabular}{|c|c|c|c|c|c|}
\hline Variables & $\begin{array}{l}\text { Indic } \\
\text { ator }\end{array}$ & Objective & $\begin{array}{l}\text { Loading } \\
\text { Factors }\end{array}$ & $\begin{array}{c}\mathbf{T} \\
\text { Statistics }\end{array}$ & Conclusion \\
\hline \multirow{8}{*}{$\begin{array}{l}\text { Environmentally } \\
\text { friendly } \\
\text { perception }\end{array}$} & $\mathrm{X} 1$ & $\begin{array}{c}\text { Knowledge of } \\
\text { Environmentally friendly } \\
\text { material }\end{array}$ & $\begin{array}{c}0,528472 \\
2\end{array}$ & 24.736 & Valid \\
\hline & $\mathrm{X} 2$ & $\begin{array}{l}\text { Indoor Water } \\
\text { Conservation }\end{array}$ & $\begin{array}{c}0,313194 \\
4\end{array}$ & 6.941 & Invalid \\
\hline & $\mathrm{X} 3$ & Rainwater Conservation & $\begin{array}{c}0,263194 \\
4\end{array}$ & 5.105 & Invalid \\
\hline & $\mathrm{X} 4$ & Energy Diversification & $\begin{array}{c}0,313194 \\
4\end{array}$ & 6.652 & Invalid \\
\hline & $\mathrm{X} 5$ & $\begin{array}{l}\text { Ozone Friendly Air } \\
\text { Conditioning }\end{array}$ & $\begin{array}{c}0,511805 \\
6\end{array}$ & 22.402 & Valid \\
\hline & $\mathrm{X} 6$ & Energy Saving & $\begin{array}{c}0,521527 \\
8\end{array}$ & 26.356 & Valid \\
\hline & $\mathrm{X} 7$ & $\begin{array}{c}\text { Domestic waste water } \\
\text { management }\end{array}$ & $\begin{array}{c}0,402777 \\
8\end{array}$ & 10.161 & Valid \\
\hline & $\mathrm{X} 8$ & Waste Sorting & $\begin{array}{c}0,410416 \\
7\end{array}$ & 14.105 & Valid \\
\hline
\end{tabular}




\begin{tabular}{|c|c|c|c|c|c|}
\hline Variables & $\begin{array}{l}\text { Indic } \\
\text { ator }\end{array}$ & Objective & $\begin{array}{l}\text { Loading } \\
\text { Factors }\end{array}$ & $\begin{array}{c}\text { T } \\
\text { Statistics }\end{array}$ & Conclusion \\
\hline \multirow{10}{*}{$\begin{array}{l}\text { Thermal } \\
\text { Comfort } \\
\text { Perception }\end{array}$} & $\mathrm{X} 9$ & $\begin{array}{l}\text { Building Occupants } \\
\text { health }\end{array}$ & $\begin{array}{c}0,559027 \\
8\end{array}$ & 30.433 & Valid \\
\hline & $\mathrm{X} 10$ & Site Sustainability & $\begin{array}{c}0,515277 \\
8\end{array}$ & 24.198 & Valid \\
\hline & X11 & Disaster Resilent & $\begin{array}{c}0,520138 \\
9\end{array}$ & 22.652 & Valid \\
\hline & Y11 & $\begin{array}{c}\text { Temperature Difference } \\
\text { between indoor and } \\
\text { outdoor }\end{array}$ & $\begin{array}{c}0,218055 \\
6\end{array}$ & 3.192 & Invalid \\
\hline & Y12 & Daily personal activities & -0.441 & 5.489 & Invalid \\
\hline & Y13 & Personal Clothing & -0.121 & 1.418 & Invalid \\
\hline & Y14 & Thermal Comfort & $\begin{array}{c}0,517361 \\
1\end{array}$ & 15.887 & Valid \\
\hline & Y15 & Thermal Comfort Desire & -0.040 & $\begin{array}{c}0,295138 \\
9\end{array}$ & Invalid \\
\hline & Y16 & $\begin{array}{l}\text { Thermal comfort } \\
\text { satisfaction }\end{array}$ & $\begin{array}{c}0,601388 \\
9\end{array}$ & 23.302 & Valid \\
\hline & Y17 & $\begin{array}{l}\text { Thermal Comfort } \\
\text { Disatisfaction }\end{array}$ & $\begin{array}{c}0,585416 \\
7\end{array}$ & 30.523 & Valid \\
\hline \multirow{3}{*}{$\begin{array}{c}\text { Energy } \\
\text { consumption } \\
\text { perception }\end{array}$} & Y21 & $\begin{array}{l}\text { Energy consumption } \\
\text { understanding }\end{array}$ & -0.574 & $\begin{array}{c}0,676388 \\
9\end{array}$ & Invalid \\
\hline & Y22 & $\begin{array}{l}\text { Incresed/Decreased } \\
\text { Energy consumption } \\
\text { understanding }\end{array}$ & 0.002 & 0.005 & Invalid \\
\hline & Y23 & $\begin{array}{l}\text { Usage of Air } \\
\text { Conditioning }\end{array}$ & $\begin{array}{c}0,579166 \\
7\end{array}$ & 1.474 & Valid \\
\hline \multirow{3}{*}{ Job Satisfaction } & Y31 & $\begin{array}{l}\text { Building Occupants job } \\
\text { satisfaction }\end{array}$ & $\begin{array}{c}0,533333 \\
3\end{array}$ & 20.582 & Valid \\
\hline & Y32 & $\begin{array}{l}\text { Work Environment } \\
\text { Satisfaction }\end{array}$ & $\begin{array}{c}0,615277 \\
8\end{array}$ & 58.472 & Valid \\
\hline & Y33 & $\begin{array}{l}\text { Indoor Air Quality } \\
\text { Satisfaction }\end{array}$ & $\begin{array}{c}0,565972 \\
2\end{array}$ & 36.168 & Valid \\
\hline \multirow{4}{*}{$\begin{array}{c}\text { Work } \\
\text { Performance }\end{array}$} & Y41 & Employee Compliance & $\begin{array}{c}0,436805 \\
6\end{array}$ & 11.502 & Valid \\
\hline & $\mathrm{Y} 42$ & Work Quantity & $\begin{array}{c}0,501388 \\
9\end{array}$ & 15.924 & Valid \\
\hline & Y43 & Budget Absorption & $\begin{array}{c}0,538888 \\
9\end{array}$ & 29.055 & Valid \\
\hline & Y44 & Working Behaviour & $\begin{array}{c}0,509722 \\
2 \\
\end{array}$ & 19.240 & Valid \\
\hline
\end{tabular}

Based on above table, not all indicator of every construct has a loading factor value above 0,5 so it can be concluded those invalid criteria can be put aside or removed to answering the 
research questions. In the table 6 below, PLS SEM also measured the path coefficient and Structural Model Test.

Table 6. Path Coefficient and Structural Model Test

\begin{tabular}{llll}
\hline & Path & $\begin{array}{l}\text { T } \\
\text { Statistics }\end{array}$ & $\begin{array}{l}\text { R } \\
\text { square }\end{array}$ \\
\hline X -> Y2 & -0.044 & 0.101 & 0.081 \\
Y4 -> Y2 & -0.262 & 0.214 & \\
X -> Y3 & 0.457 & 0.049 & 0.384 \\
Y1 -> Y3 & 0.313 & 0.047 & \\
Y1 -> Y4 & 0.001 & 0.063 & 0.249 \\
Y3 -> Y4 & 0.499 & 0.054 & \\
\hline
\end{tabular}

As seen in Table above, A link between Environmental Perception (EP) and Work Performance to Energy consumption is measured 0,081. It means Energy consumption can be explained by Environmentally friendly perception and work performance for $8,1 \%$. The rest of it $(91,9 \%)$ could be explained by other unexamined variables. Based on other research by [3], [9] this might be related to unexamined variables in this research such as: Personal factors or even outdoor climate during the examination.

Moreover, link between Environmental Perception (EP) and Thermal Comfort to Job Satisfaction is measured 0,384. It means Job Satisfaction can be explained by Environmentally friendly perception and work performance for $38,4 \%$. The rest of it $(61,6 \%)$ could be explained by other unexamined variables. Based on other research by [3], [9] this might be related to unexamined variables in this research such as: Personal satisfaction or even outdoor climate during the examination.

Moreover, the PLS-SEM measurement is trying to answer the hypotheses shown above, the results can be seen in Table 7 below:

Table 7. Test the hypotheses

\begin{tabular}{|c|c|c|c|c|c|c|c|c|}
\hline $\begin{array}{l}\text { ypothe } \\
\text { ses }\end{array}$ & $\begin{array}{c}\text { Path } \\
\text { Coeffic } \\
\text { ient } \\
\text { (Before } \\
\text { interve } \\
\text { ntion) }\end{array}$ & $t_{\text {count }}$ & $\begin{array}{c}\mathbf{t}_{\text {critica }} \\
\quad \mathrm{I}\end{array}$ & $\begin{array}{c}\begin{array}{c}\text { Result } \\
\text { (before }\end{array} \\
\text { interventio } \\
\text { n) }\end{array}$ & $\begin{array}{c}\text { Path } \\
\text { Coefficie } \\
\text { nt (After } \\
\text { Interven } \\
\text { tion) }\end{array}$ & $t_{\text {count }}$ & $\begin{array}{c}\mathbf{t}_{\text {critica }} \\
\quad 1\end{array}$ & $\begin{array}{c}\text { Result } \\
\text { (After } \\
\text { intervent } \\
\text { ion) }\end{array}$ \\
\hline $\mathrm{Ha} 1$ & -0.044 & $\begin{array}{c}0,2986 \\
111\end{array}$ & 1,96 & Rejected & 0.006 & 0.096 & 1,96 & Rejected \\
\hline $\mathrm{Ha} 2$ & -0.262 & 1.226 & 1,96 & Rejected & -0.221 & 3.859 & 1,96 & Accepted \\
\hline $\mathrm{Ha} 3$ & 0,317 & 9.389 & 1,96 & Accepted & 0,327 & 9.348 & 1,96 & Accepted \\
\hline
\end{tabular}




\begin{tabular}{lllllllll} 
Ha4 & 0,217 & 6.611 & 1,96 & Accepted & 0,209 & 6.013 & 1,96 & Accepted \\
Ha5 & 0.001 & 0.010 & 1,96 & Rejected & -0.035 & 0,424 & 1,96 & Rejected \\
\hline
\end{tabular}

Ha1: Thermal comfort does not impacted Building Energy Consumption

Ha2: Building perception to sustainable has a correlation to energy consumption

Ha3: Thermal comfort in government building influencing building occupants work performance

Ha4: Thermal comfort has a correlation to work satisfaction

Ha5: Public facility building is not related thermal comfort and work satisfaction

Acknowledgements. The authors would like to thank Universitas Indonesia for supporting our research under grand scheme Hibah Publikasi Internasional Terindeks untuk Tugas Akhir Mahasiswa A (PITMA-A) Number: NKB-0886/UN2.R3.1/HKP.05.00/2019

\section{References}

[1] Y. Zhang, J. Wang, F. Hu, and Y. Wang, "Comparison of evaluation standards for green building in China, Britain, United States,” Renew. Sustain. Energy Rev., vol. 68, no. August 2016, pp. 262271, 2017.

[2] Y. H. Yau, "Thermal comfort and Indoor Air Quality at Green Building in Malaysia," 2010.

[3] A. Merabtine, C. Maalouf, A. Al Waheed Hawila, N. Martaj, and G. Polidori, "Building energy audit, thermal comfort, and IAQ assessment of a school building: A case study," Build. Environ., vol. 145, no. July, pp. 62-76, 2018.

[4] L. Pomfret and A. Hashemi, "ScienceDirect ScienceDirect Thermal Comfort in Zero Energy Buildings," Energy Procedia, vol. 134, pp. 825-834, 2017.

[5] S. Barbhuiya and S. Barbhuiya, "Thermal comfort and energy consumption in a UK educational building," Build. Environ., vol. 68, pp. 1-11, 2013.

[6] P. O. Fanger and J. Toftum, "Extension of the PMV model to non-air-conditioned buildings in warm climates," vol. 34, pp. 533-536, 2002.

[7] M. A. Nico, S. Liuzzi, and P. Stefanizzi, "Evaluation of thermal comfort in university classrooms through objective approach and subjective preference analysis," Appl. Ergon., vol. 48, pp. 111$120,2015$.

[8] M. Kameni, R. Tchinda, and J. A. Orosa, "Thermal comfort and energy consumption in modern versus traditional buildings in Cameroon : A questionnaire-based statistical study," vol. 114, pp. 687-699, 2014.

[9] S. Tanabe, M. Haneda, and N. Nishihara, "Workplace productivity and individual thermal satisfaction," Build. Environ., vol. 91, pp. 42-50, 2015.

[10] M. T. H. Derks, A. K. Mishra, M. G. L. C. Loomans, and H. S. M. Kort, "Understanding thermal comfort perception of nurses in a hospital ward work environment," Build. Environ., vol. 140, no. March, pp. 119-127, 2018.

[11] M. Holmgren, A. Kabanshi, and P. Sörqvist, "Occupant perception of 'green' buildings: Distinguishing physical and psychological factors," Build. Environ., vol. 114, pp. 140-147, 2017.

[12] A. Botelho, L. M. C. Pinto, L. Lourenço-Gomes, M. Valente, and S. Sousa, "Public Perceptions of Environmental Friendliness of Renewable Energy Power Plants," Energy Procedia, vol. 106, pp. 73-86, 2016.

[13] S. Hubbard, K. Stewart, and J. Fan, "Modeling spatiotemporal patterns of building vulnerability and content evacuations before a riverine flood disaster," Appl. Geogr., vol. 52, pp. 172-181, 2014. 
[14] S. Khandelwal, R. Goyal, N. Kaul, and A. Mathew, "The Egyptian Journal of Remote Sensing and Space Sciences Assessment of land surface temperature variation due to change in elevation of area surrounding Jaipur , India," Egypt. J. Remote Sens. Sp. Sci., vol. 21, no. 1, pp. 87-94, 2018.

[15] T. N. Phan, "Land Surface Temperature Variation Due to Changes in Elevation in Northwest Vietnam,” pp. 1-20, 2018.

[16] J. Student, E. Papyrakis, and P. Van Beukering, "Buildings behaving badly: a behavioral experiment on how different motivational frames influence residential energy label adoption in the Netherlands," J. Hous. Built Environ., vol. 32, no. 1, pp. 107-132, 2017.

[17] J. Langevin, J. Wen, and P. L. Gurian, "Quantifying the human-building interaction: Considering the active, adaptive occupant in building performance simulation," Energy Build., vol. 117, pp. 372-386, 2016.

[18] B. Andalas, H. Kusnoputranto, and R. H. Koestoer, "Developing thermal comfort model through regional budget expenditure analysis towards low energy consumption in public building facility (case object: government building in north and south of Jakarta)," E3S Web Conf., vol. 74, p. 05001, 2018.

[19] H. Boesono, D. R. Setiawan, K. E. Prihantoko, B. B. Jayanto, and A. R. Malala, "Productivity Analysis of Mini Purse Seine in PPI Pulolampes Brebes, Central Java, Indonesia," Aquat. Procedia, vol. 7, pp. 112-117, 2016.

[20] B. G. Tabachnick and L. S. Fidell, "Using Multivariate Statistics Title: Using multivariate statistics (Vol. 5)," pp. 1-14, 2007.

[21] S. Kaur, R. Sharma, R. Talwar, A. Verma, and S. Singh, "A study of job satisfaction and work environment perception among doctors in a tertiary hospital in Delhi," Indian J. Med. Sci., vol. 63, no. 4, p. 139, 2009.

[22] Y. Geng, W. Ji, B. Lin, and Y. Zhu, "The impact of thermal environment on occupant IEQ perception and productivity," Build. Environ., vol. 121, pp. 158-167, 2017.

[23] H. Ma, W. Lu, L. Yin, and X. Shen, "Public Building Energy Consumption Level and Influencing Factors in Tianjin," Energy Procedia, vol. 88, pp. 146-152, 2016.

[24] J. K. Day and D. E. Gunderson, "Understanding high performance buildings: The link between occupant knowledge of passive design systems, corresponding behaviors, occupant comfort and environmental satisfaction," Build. Environ., vol. 84, pp. 114-124, 2015.

[25] M. S. Farooq, M. Salam, A. Fayolle, N. Jaafar, and K. Ayupp, "Impact of service quality on customer satisfaction in Malaysia airlines: A PLS-SEM approach," J. Air Transp. Manag., vol. 67, no. January, pp. 169-180, 2018.

[26] J. F. Hair, M. Sarstedt, C. M. Ringle, and J. A. Mena, "An assessment of the use of partial least squares structural equation modeling in marketing research," pp. 414-433, 2012.

[27] D. J. Ketchen, "A Primer on Partial Least Squares Structural Equation Modeling," Long Range Plann., vol. 46, no. 1-2, pp. 184-185, 2013.

[28] M. S. Farooq et al., "Acceptance and use of lecture capture system (LCS) in executive business studies: Extending UTAUT2,” Interact. Technol. Smart Educ., vol. 14, no. 4, pp. 329-348, 2017. 